\title{
OUTGOING LONGWAVE RADIATION AT THE TOP OF THE ATMOSPHERE: PRELIMINARY ASSESSMENT USING GOES-8 IMAGER DATA
}

\author{
Juan Carlos Ceballos, Wagner Flauber Araújo Lima, ${ }^{2}$ Jaidete Monteiro de Souza ${ }^{3}$ \\ Recebido em 6 fev. 2003 / Aceito em 10 fev., 2004 \\ Received Feb. 6, 2003 / Accepted Feb. 10, 2004
}

\begin{abstract}
GOES-8 Imager radiances in water vapor and infrared channels 3, 4 and 5 were used for assessing outgoing longwave radiation (OLR) at the top of the atmosphere. Estimation by ITPP5 software applied to HIRS/NOAA 14 passes over Brazil was considered as "true reference". Imagery from both satellites is currently acquired and processed at CPTEC/INPE. GOES full-resolution imagery allows assessment of mean irradiance for sets of GOES pixels contained within the area of a single HIRS pixel. Additional GOES variables were estimated, such as: an "equivalent channel" at $8 \mathrm{~mm}$ and a "longwave tail" for $\mathrm{l}>15 \mathrm{~mm}$ (this one is not detected neither by HIRS nor GOES sensors). Isotropic outgoing radiance was assumed. Multivariate regression of GOES irradiances on OLR ITPP estimates provided a GOES estimator with accuracy comparable with others already published and based on AVHRR/NOAA information. It was found that a regression based only on channel 4 and the longwave tail yielded estimates with the same accuracy: mean deviation of $3 \mathrm{~W} \cdot \mathrm{m}^{-2}$ and standard deviation of $11 \mathrm{~W} \cdot \mathrm{m}^{-2}$. The application for another period in the year, averaged over $1^{\circ} 1^{\circ}$ grid cells, yielded similar mean deviation and standard deviation of $7 \mathrm{~W} . \mathrm{m}^{-2}$. These results suggest that the algorithm applied in this work has physical rather than purely statistical meaning and could be used for OLR monitoring in daily and seasonal scales.
\end{abstract}

Keywords: Outgoing Longwave Radiation (OLR), GOES 8 Imager, NOAA 14, Terrestrial Radiation

\section{RESUMO}

Radiâncias obtidas do satélite GOES 8 nos canais de vapor d'água e infravermelho termal (2, 4 e 5) foram utilizadas para estimar Radiação de Onda Longa (ROL) emergente no topo da atmosfera. As estimativas de ROL pelo utilitário ITPP5, aplicadas à informação do sensor HIRS/NOAA, foram consideradas como "verdade de referência". Imagens dos dois satélites são continuamente recebidas e processadas no CPTEC/INPE. As imagens GOES de alta resolução permitiram considerar grupos de pixels (e a irradiância média correspondente) contidos na área de um único pixel HIRS. Variáveis adicionais foram elaboradas, como por exemplo: um "canal equivalente" em $8 \mathrm{~mm}$ e uma "cauda espectral de onda longa" para I > $15 \mathrm{~mm}$ (esta última, não detectada nem pelo HIRS nem pelo GOES). Assumiu-se a hipótese de isotropia para a radiância emergente. Regressão multivariada das irradiâncias GOES com relação à estimativa ITPP da ROL forneceu um estimador GOES com precisão comparável à de outros já publicados e baseados na informação de AVHRR/NOAA. Verificou-se que uma regressão baseada apenas nas irradiâncias do canal 4 e da cauda de onda longa fornece estimativas com a mesma precisão: erro médio de 3 W. $\mathrm{m}^{-2}$ e desvio padrão de 11 W. $\mathrm{m}^{-2}$. A aplicação do algoritmo para outra época do ano, avaliando médias em células de $1^{\circ} 1^{\circ}$, produz um desvio médio similar e um desvio padrão de 7 W. $\mathrm{m}^{-2}$. Estes resultados sugerem que o algoritmo resgatou propriedades físicas e não simplesmente estatísticas da ROL, e poderia ser aplicado para monitoramento de ROL em escala diária e sazonal.

Palavras-chave: Radiação de Onda Longa Emergente (ROL), GOES 8, NOAA 14, Radiação Terrestre.

\footnotetext{
CPTEC/INPE - 12630 Cachoeira Paulista (SP) - Brazil. E-mails: ceballos@cptec.inpe.br.

CPTEC/INPE - 12630 - Cachoeira Paulista (SP) - Brazil. E-mail: wagner@cptec.inpe.br.

CPTEC/INPE - 12630 - Cachoeira Paulista (SP) - Brazil. E-mail: jaidete@ cptec.inpe.br.
} 


\section{INTRODUCTION}

The Outgoing Longwave Radiation (OLR) at the top of the atmosphere (TOA) is an important meteorological variable, used in several ways. On one hand, it is used by the meteorological community as an index related to convective activity since lower OLR values are associated to the top height of well developed clouds (SCHMETZ; LIU, 1988). On the other hand, the OLR is the infrared component of the Earth's energy balance. Together with the solar net radiation flux, it helps to describe the changes in energy availability induced by clouds through the difference between clear-sky and the observed radiative balances (RAMANATHAN et al., 1989).

Early operational assessments of OLR employed a simple parameterization using the window channel brightness temperature of the AVHRR/NOAA 6-7 system (ELLINGSON; FERRARO, 1983; GRUBER; KRUEGER, 1984). ELLINGSON and others (1989) have shown that linear combination of only four HIRS channels could account for more than 99\% of the OLR total variance. Comparison with the ERBE (Earth Radiation Budget Experiment) instrument flown in NOAA 9-11 satellites suggested that estimates made with HIRS data exhibited errors of the same order of ERBE: about 5 W.m.-2 (ELLINGSON; LEE; YANUK, 1994), and the use of AVHRR data exhibits monthly bias of -1 to $+2 \mathrm{~W} \cdot \mathrm{m}^{-2}$ and rms differences of about 14 W.m-2 (GRUBER et al., 1994). Presently, NOAA/NESDIS assessments of OLR use the AVHRR channel 4, or four HIRS/TOVS or HIRS/ATOVS channels through a linear regression of brightness temperatures (Jacobowitz, Herbert, NOAA, personal communication). NCEP (National Center for Environmental Prediction) provides two daily OLR fields which are averages for a grid of $2.5^{\circ} 2.5^{\circ}$. After 1985, the algorithms have changed. NOAA-16 ATOVS data are being used but no further calibration has been published (KIDDER; VONDER HAAR, 1995). CERES (Clouds and the Earth's Radiant Energy System) has replaced the ERB sensor, being flown onboard TRMM satellite (Tropical Rainfall Measuring Mission) and EOS-AM ("Terra") satellites (BAKSTROM, 1999), allowing to perform new comparisons with TOVS/ ATOVS based algorithms.

Geostationary satellites imagery has also been used for OLR assessment. Gube (1982) and Schmetz \& Liu (1988) have reported parameterizations using two channels (water vapor and thermal infrared) of the Meteosat. Mamoudou \& Ellingson (2001) estimated OLR using several channels of the GOES Sounder (instead of HIRS/NOAA) and presented comparisons with the CERES measurements. Nevertheless, these are preliminary results. Based on GOES-7 imagery and ground data during ABLE (Amazon Boundary Layer Experiment), Calvet \& Viswanadham (1993) suggested that a linear relation may exist be- tween TOA radiation balance and the net radiation at ground level. GOES-7 had only two channels (visible and infrared window).

GOES-8 Imager full-resolution data are presently available with four channels in the infrared region. Channels 2, 4 and 5 are located at spectral frequencies similar to channels 3,4 and 5 of the AVHRR sensor. Also, channel 3 provides additional information in wavelengths not covered by the AVHRR. It is worthwhile to note that the (global) field of OLR provided by NCEP actually presents information of successive orbits of the same NOAA satellite (therefore, it describes estimated OLR for similar local solar time throughout the globe along 24 hours). Time frequencies of GOES imagery suggest its use for instantaneous assessment of OLR following up its daily cycle over large areas. Keeping that possibility in mind, the present paper examines aspects of the performance of a simple algorithm based on GOES Imager information and adjusted to OLR assessments by ITPP (International TOVS Processing Package).

\section{CONCEPTUAL FRAME FOR THE OLR ASSESSMENT}

In clear-sky conditions, the spectral radiance $L_{v}(\mu)$ emerging at the TOA with zenith angle $q(\mathrm{~m}=\cos q)$ can be formally described by:

$$
\begin{aligned}
& L_{v}(v, u)=\varepsilon_{v} B_{v}(v ; T) \cdot \exp \left[\tau_{v}(0) / \mu\right]+ \\
& +\int_{0}^{\infty} B_{v}[v ; T(z)] \cdot \exp \left[\tau_{v}(z) / \mu\right] \cdot \kappa_{v} \rho(z) \cdot d z / \mu \\
& \tau_{v}(z)=\int_{z}^{\wp} \kappa_{v}(z) \rho(z) d z
\end{aligned}
$$

where $B_{v}$ denotes the Planck's function for frequency $n$ at temperature $\tau ; z=$ altitude; $\tau_{v}=$ optical depth from TOA until altitude $z ; \rho=$ density or concentration of absorbing material; $\kappa_{v}=$ mass absorption coefficient of the absorber; $\varepsilon_{v}=$ ground emissivity.

Eq. (1) describes $L_{v}$ at TOA as the sum of radiation emitted by the ground with a temperature $T_{s}$ and attenuated by the atmosphere, plus the contributions of successive layers with optical depth $d \tau_{v}=\kappa_{v} \cdot \rho(z) \cdot d z$ (note that $d \tau_{v} \square 1$ implies its equivalence with absorptance thus with emittance of the layer for that wavelength); exponential function describes attenuation until emerging at the TOA. Note also that pressure can be adopted as altitude variable instead of $z$. Scattering is considered negligible so that attenuation is associated to absorption only; emitted radiance is assumed azimuth independent. The 
irradiance at TOA can be obtained by integration over the upward hemisphere:

$$
E_{v T O A}^{\uparrow}(v)=2 \pi \int_{0}^{1} \mu L_{v}(v, \mu) d \mu
$$

It can be shown that eq. (3) is equivalent to (LIOU, 1980):

$$
\begin{aligned}
& E_{v T O A}^{\uparrow}(v)=2 \pi \varepsilon_{v} B_{v}(v ; T) \cdot \Psi_{3}\left(\tau_{v s}\right)+ \\
& +\int_{0}^{p s} 2 \pi B_{v}[v ; T(p)] \frac{d \Psi_{3}\left(\tau_{v}\right)}{d \tau_{v}} d \tau_{v},
\end{aligned}
$$

where $\Psi_{n}(\tau)$ is the so-called exponential-integral function of $n$-th order:

$$
\Psi_{n}(\tau)=\int_{1}^{\infty} x^{-n} \exp (-x \tau) d x
$$

and $22 \Psi_{3}\left(\tau_{v}\right)=\Psi_{v}^{0}$ represents the monochromatic transmittance for (initially) isotropic diffuse radiation emitted at the optical depth $\tau_{v}$.
Absorption in this atmosphere is produced mainly by $\mathrm{H}_{2} \mathrm{O}$ vapor, $\mathrm{CO}_{2}$ and $\mathrm{O}_{3}$ in several absorption bands constituted by a high number of absorption lines. Molecular collisions produce line broadening so that $\tau_{v}$ and $\Psi_{v}^{0}$ exhibit a complex spectral structure: monochromatic transmittance depends not only on the spectral environment but also on vertical profile of atmospheric absorbers. Line-by-line methods allow integration (and further parameterizations) over narrow intervals Dn providing mean transmittance $\Psi_{v}$ over $\Delta v$ for a central frequency $n$ and optical path $w$, weighted with vertical profiles $\rho(z)$ of the absorber as well as temperature $T(z)$ and pressure $p(z)$. In this work, we use the SBDART, acronym of Santa Barbara DISORT Atmospheric Radiative Transfer (RICHIAZZI et al., 1998). This software is available on the internet (RICCHIAZZI; YANG; GAUTIER, 2000). It allows to assess transmittances in interval widths $\Delta v=20 \mathrm{~cm}^{-1}$, as well as perform calculation of outgoing spectral irradiance $E_{v T O P}^{\uparrow}$ for different atmospheric profiles. It also allows the inclusion of stratiform clouds at chosen levels; in this case $T_{s}$ and e for $z=0$ in the right term of eq. (4) correspond to the cloud top if the cloud is optically thick.

Figure 1 shows a theoretical spectrum obtained by SBDART for a tropical model atmosphere with no aerosol. The spectral variable is wave-

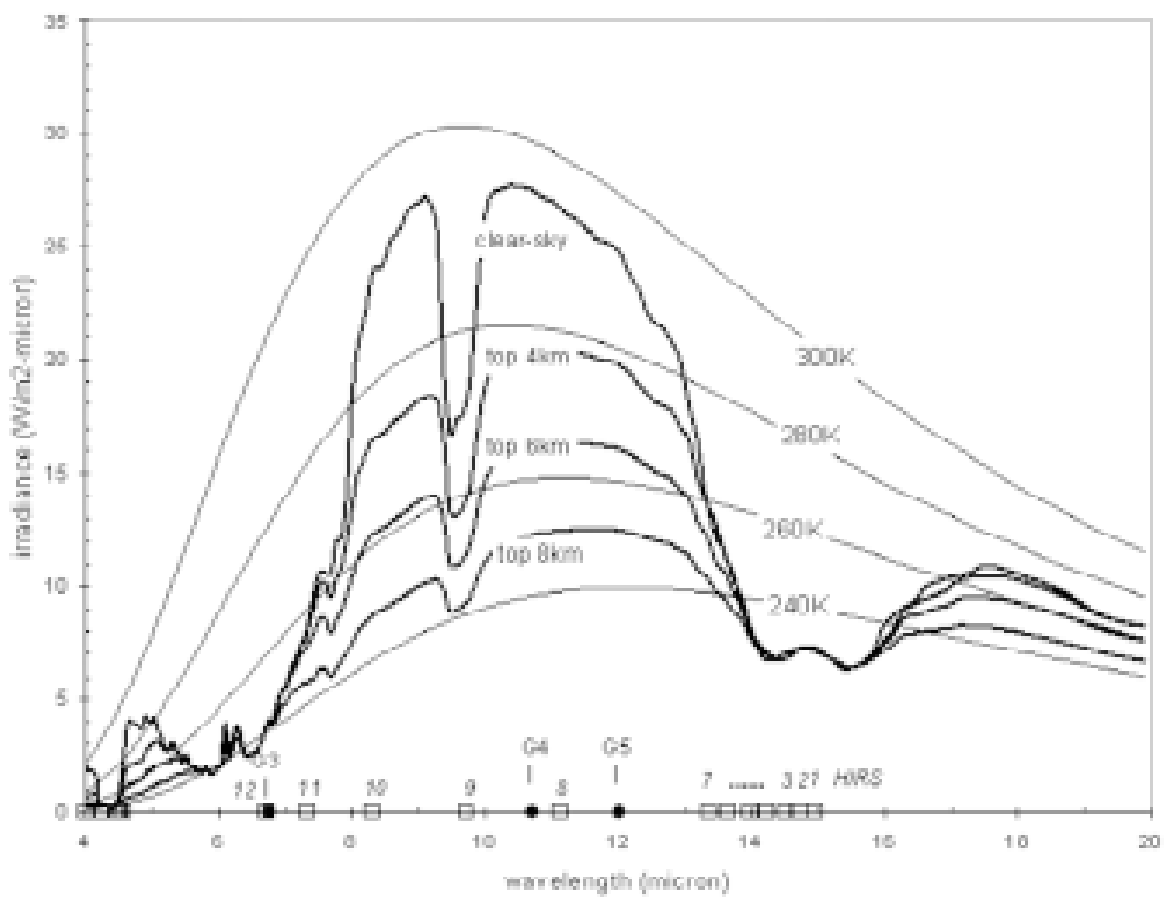

Figure 1 - OLR spectrum for a McClatchey's tropical model atmosphere. Figura I - Espectro de ROL para uma atmosfera modelo tropical de McClatchey. 
length I instead of frequency n. Blackbody spectrums for several temperatures are included, for the sake of illustration of atmospheric effects. As expected, the irradiance emerging at TOA departs considerably from blackbody spectrum. Several TOA spectrums for a $2 \mathrm{~km}$ thick cloud imbedded in this atmosphere are also shown. For the clear-sky case, it is seen that the water vapor band at $6.4 \mathrm{~mm}$ entirely absorbs the ground thermal radiation. Emerging irradiance is mainly due to the vapor emission within mid- and upper-troposphere. As a consequence, brightness temperature is typically about $T_{\mathrm{b}}=240 \mathrm{~K}$. Stratospheric ozone emits in a band around $9.6 \mathrm{~mm}$; nevertheless, ground irradiance is higher and the net effect is a spectral decrease due to the ozone absorption. Carbon dioxide band around $15 \mathrm{~mm}$ strongly absorbs ground radiation, so that $T_{\mathrm{b}}$ at this band center is about 220K corresponding to a nearly stratospheric emission. Wavelengths of about $11 \mu \mathrm{m}$ show the "atmospheric window" where basically only weak absorption by water vapor continuum is present; therefore, $T_{\mathrm{b}}$ is rather close to but lower than ground temperature $T_{\mathrm{s}}$. For a tropical atmosphere with high values of moisture at lower layers, $T_{\mathrm{b}}$ may differ considerably from $T_{\mathrm{s}}$.

The presence of clouds with tops at 4,6 and $8 \mathrm{~km}$ heights conserve the general trends of clear-sky TOA irradiance, but brightness temperature decreases and water vapor effect weakens with top height. Atmospheric window irradiances at $10.5-12 \mu \mathrm{m}$ are nearly constant, tending to cloud top thermodynamic temperature for higher clouds. On the other hand, note that $T_{\mathrm{b}}$ in $14.5-15 \mu \mathrm{m}$ is always the same, due to the strong absorption by $\mathrm{CO}_{2}$ within the higher atmosphere.

In what follows, integration of spectral radiance $L_{\lambda}$ instead of $L_{v}$ will be considered. Figure 1 includes information about spectral position of different infrared channels of HIRS instrument onboard NOAA14 and of GOES-8 imager, located on the abscissa axis. It can be said that:

a) satellites detect spectral radiance which is not isotropic. Line-of-sight from pixel to satellite implies an attenuation varying with the zenith angle $\theta_{\mathrm{s}}$. A pixel in a given geographical location is viewed by NOAA and GOES satellites with different $\theta_{s}$.

b) HIRS channels 13-19 virtually do not contribute to the OLR.

c) GOES and HIRS channels in $6.4 \mu \mathrm{m}$ water vapor band represent minor contributions to the total irradiance.

d) When integrating $L_{\lambda}$ within the $(8-10 \mu \mathrm{m})$ interval, HIRS channels 8-10 do not accurately assess contribution of ozone absorption in clear-sky conditions. This might not be the case for cloudy scenes (for which ozone depletion is lower).

e) Atmospheric window channel 8 for NOAA and channels 4-5 for GOES describe an important contribution to total irradiance.

f) Spectral decrease due to $\mathrm{CO}_{2}$ band is detected in detail by NOAA channels 1-7. GOES provides no information in the $\mathrm{CO}_{2}$ band. g) Neither HIRS nor GOES provide information for the interval $\lambda>16 \mu \mathrm{m}$, which contains an important contribution to the total irradiance.

The attempt to assess OLR through a linear regression on HIRS radiances constitutes an implicit integral over the whole longwave spectrum. ITPP5 software ("International TOVS Processing Package") has been widely used for assessing atmospheric retrievals based on HIRSMSU/NOAA radiances. Version 5 includes a procedure for estimation of OLR through a linear combination of brightness temperature in 12 HIRS channels. Nevertheless, a theoretical study by Ellingson and others (1989) showed that four channels would be enough for recovering $99 \%$ of total variance in a linear regression (considering the case $\theta_{\mathrm{s}}=0$ ). In particular, channel 7 (within 13.1-13.6 $\mu \mathrm{m}$ ) was responsible for $96.4 \%$, whereas early use of AVHRR channel 4 in the same satellite would recover only $94 \%$. They considered a high number of atmospheric profiles and the theoretical responses of HIRS channels in NOAA-9. In terms of rms errors, that means $7 \mathrm{~W} . \mathrm{m}^{-2}$ for AVHRR, $5.5 \mathrm{~W} . \mathrm{m}^{-2}$ using channel 7 , and about $1.2 \mathrm{~W} . \mathrm{m}^{-2}$ using four channels. Including instrumental noise, the least rms error attained was $2 \mathrm{~W}$. $\mathrm{m}^{-2}$. These results strongly suggest that the upwelling spectrum is internally redundant, in such a manner that a reduced number of HIRS channels provide enough information, even about the spectral tail for $\lambda>16 \mu \mathrm{m}$. In this sense, channel 7 in NOAA-14 instrument presents at the same time information about atmospheric window and depletion by $\mathrm{CO}_{2}$; on the other hand, channel 8 in $11 \mu \mathrm{m}$ (typical of the atmospheric window) seems to exhibit a brightness temperature similar to channel 10 in $8 \mu \mathrm{m}$.

It is worthwhile to note that radiances are directional quantities, which would depend on the line-of-sight zenith angle $Z$ (that is, on total atmospheric optical path as well as on anisotropy of radiation emitted by observed targets). Usually a "limb darkening correction" for each channel reduces radiances to $Z=0$ emission, and $0 L R$ is assessed through a suitable (linear) combination of the "corrected" radiances or brightness temperatures. In a general sense, a correction factor $f\left(v, \theta_{s}\right)$ accounting for radiance anisotropy would be necessary, so that the contribution to spectral irradiance in a given channel (eq. 4) is $E_{v}=f . \pi L_{v}$.

\section{DATA AND METHODS}

\section{Satellite data}

Julian days 165, 166, 170, 173 (June) and 239 (0ctober) for 2001 were analyzed, considering NOAA 14 passage for about 0700 UT recorded in Cuiabá, MT and Cachoeira Paulista, SP stations and the 
closest GOES-8 full-disk image (that is, 0600 UT image). Figure 2 illustrates the distribution of TOVS pixels for NOAA 14 passage over Brazil in June 14, 2001 detected by INPE's ground station in Cachoeira Paulista. Only those TOVS pixels taken for atmospheric retrieval are shown, assumed by ITPP as having clear-sky conditions.
OLR values and atmospheric profiles were provided by ITPP5.0 soffware, including geographical location $\phi, \zeta(\phi=$ latitude, $\zeta=$ longitude) and brightness temperatures for all HIRS channels. ITPP5 was set for assessing OLR in all pixels. For the sake of comparison with HIRS information, a set of GOES pixels located within about $10 \mathrm{~km}$ around a

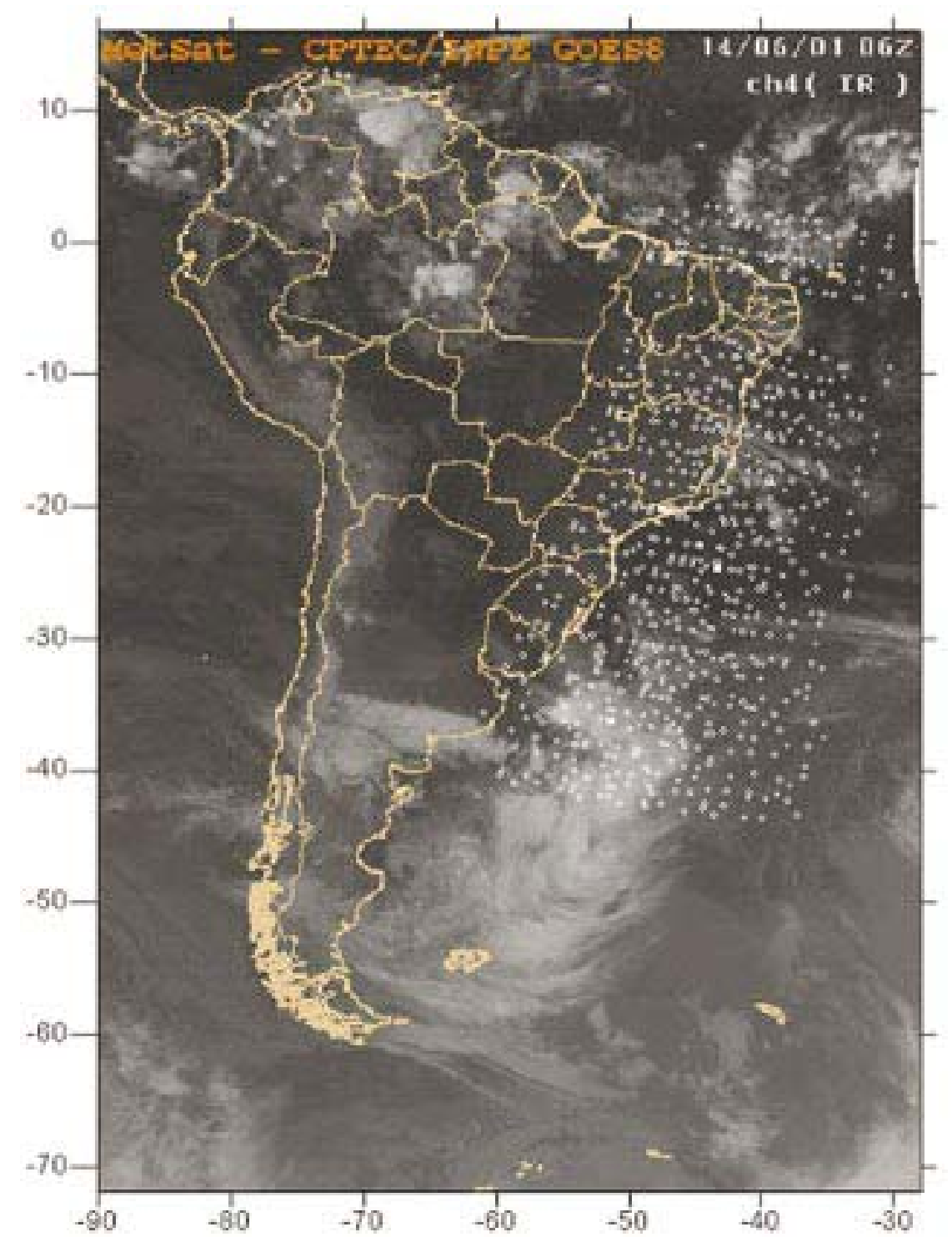

Figure 2 - Distribution of HIRS pixels (empty circles) for June 14, 2001, as detected by ground station at Cachoeira Paulista, SP (white square at about $20^{\circ} \mathrm{S}$ $\left.47^{\circ} \mathrm{W}\right)$. Spectral irradiances shown in Figure 3 correspond to white squares on the Atlantic

Figura 2 - Distribuição de pixels HIRS (círculos) para 14/06/2002, na imagem recebida pela estação de Cachoeira Paulista, SP (quadrado branco em $20^{\circ}$ S 470 W aproximadamente). Irradiâncias espectrais na Figura 3 correspondem aos quadrados brancos sobre o Atlântico. 
location $(\phi, \zeta)$ was taken. Full resolution GOES imagery was available, each pixel having about 4 ' $4 \mathrm{~km}$ size; physical informations provided by the station software were brightness temperature $I_{b}$ for channels 2 to 5 .

Radiances were assessed using Planck's law $L_{\lambda}=$ $=B_{\lambda}\left(\lambda, T_{b}\right)$, and average values within each set were calculated. It was observed that $\pm 2 \mathrm{~km}$ variations in the radius around the locations did not introduce significant differences in average radiance.

\section{Parameterizations of GOES Imager information}

Figure 3 shows two cases of radiances observed in 19 HIRS channels (as processed by ITPP5.0 soffware) and 3 infrared GOES channels. In all cases spectral irradiance was assessed as $\pi L_{\lambda}=\pi B_{\lambda}\left(\lambda, T_{b}\right)$, without the correction factor for anisotropy (that is, $f=1$ ).

Figures 3 and 4 present two extreme cases: cloud-free (high OLR value) and overcast (lowest OLR values), showing SBDART estimates of outgoing spectrum. Atmospheric profiles correspond to retrievals obtained using ITPP5.0 software. Figure 3 includes all HIRS and GOES channels estimates up to $15 \mu \mathrm{m}$. Several blackbody spectrums are presented for different temperatures. Figure 4 presents the same SBDART results and blackbody spectrums for $\lambda>15 \mu \mathrm{m}$.
SBDART estimation of spectral irradiance in a cloudy case considered the atmospheric profile for that pixel, locating top height accordingly to window channel $8(\lambda \approx 11 \mu \mathrm{m})$, for which water vapor absorption over cloud is minimal. It is seen a satisfactory fit between HIRS and GOES observations and SBDART estimates, suggesting that irradiance beyond $\lambda=15 \mu \mathrm{m}$ is accurately assessed.

It is seen that: a) a correction factor $A\left(v, \theta_{\mathrm{s}}\right)$ accounting for anisotropy could improve irradiance assessment but seems not essential; b) SBDART radiances in $15 \mu \mathrm{m} \mathrm{CO}$ band are somewhat different from HIRS measurements; nevertheless, it is found that associated error in OLR is not higher than $1 \mathrm{~W} \cdot \mathrm{m}^{-2}$.

Figures 3 and 4 suggest to assume the following algorithm for integral over infrared spectrum, based on GOES radiances:

$$
\begin{aligned}
& O L R=\int_{3.9}^{\infty} E_{\lambda} d \lambda \approx a_{0}+a_{6} \pi B_{\lambda}\left(\lambda_{6}, T_{6}\right)+ \\
& +a_{8} \pi B_{\lambda}\left(\lambda_{8}, T_{11}\right)+a_{11} \pi B_{\lambda}\left(\lambda_{11}, T_{11}\right)+ \\
& +a_{12} \pi B_{\lambda}\left(\lambda_{12}, T_{12}\right)+\int_{\lambda *}^{\infty} \pi B_{\lambda}\left(\lambda, T^{*}\right) d \lambda
\end{aligned}
$$

Here, indexes 6,11 and 12 refer to the characteristic wavelength of those channels so that coefficients $a_{6^{\prime}} a_{11}$ and $a_{12}$ are weights

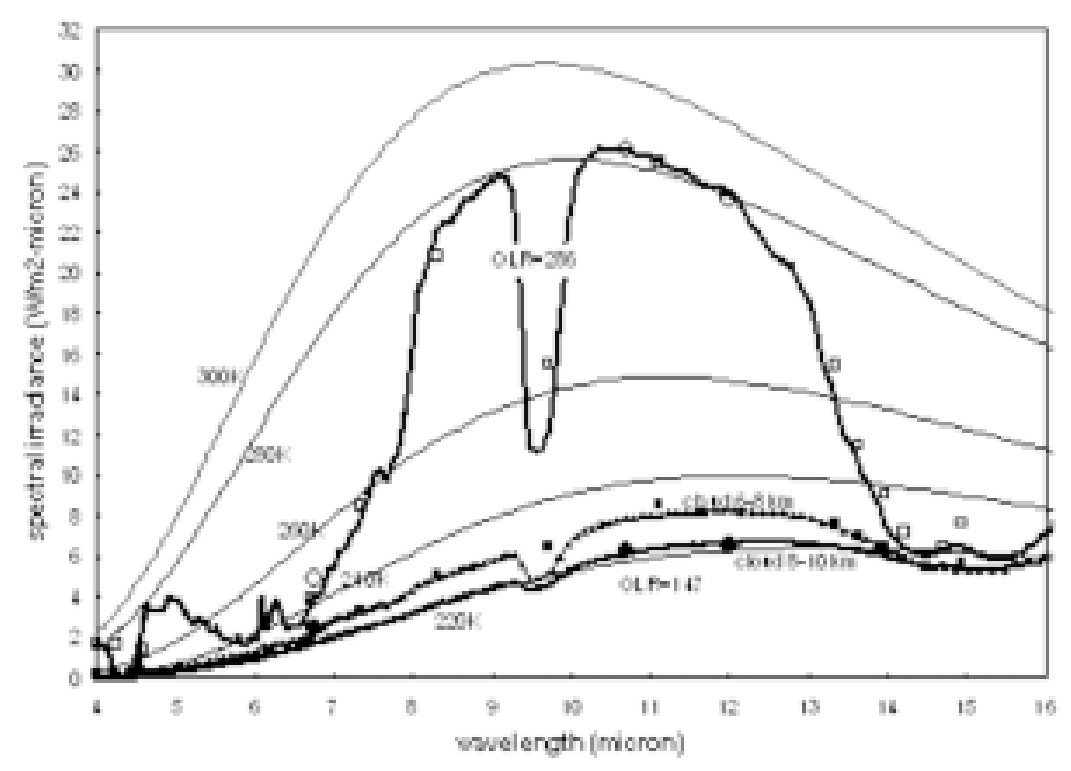

Figure 3 - Spectral irradiances during passage of NOAA 14 for two selected pixels (see position in Figure 2). Squares ( $\square$ ) are HIRS radiances; circles ( $\bigcirc \bullet$ ) are GOES averages over a circle of $15 \mathrm{~km}$ radius within the HIRS pixel area. Typical blackbody spectrums are shown for several temperatures. Estimated irradiance spectrum is also included as assessed by SBDART.

Figura 3 - Irradiâncias espectrais durante a passagem do NOAAI4 para dois pixels (ver localização na Figura 2). Os quadrados ( $\square$ ) são radiância HIRS; os círculos ( O• ) são médias de GOES num círculo de $15 \mathrm{~km}$ de rádio na área do pixels HIRS. Mostram-se espectros típicos de corpo negro para várias temperaturas. Também é incluído o espectro de irradiâncias calculado mediante SBDART. 


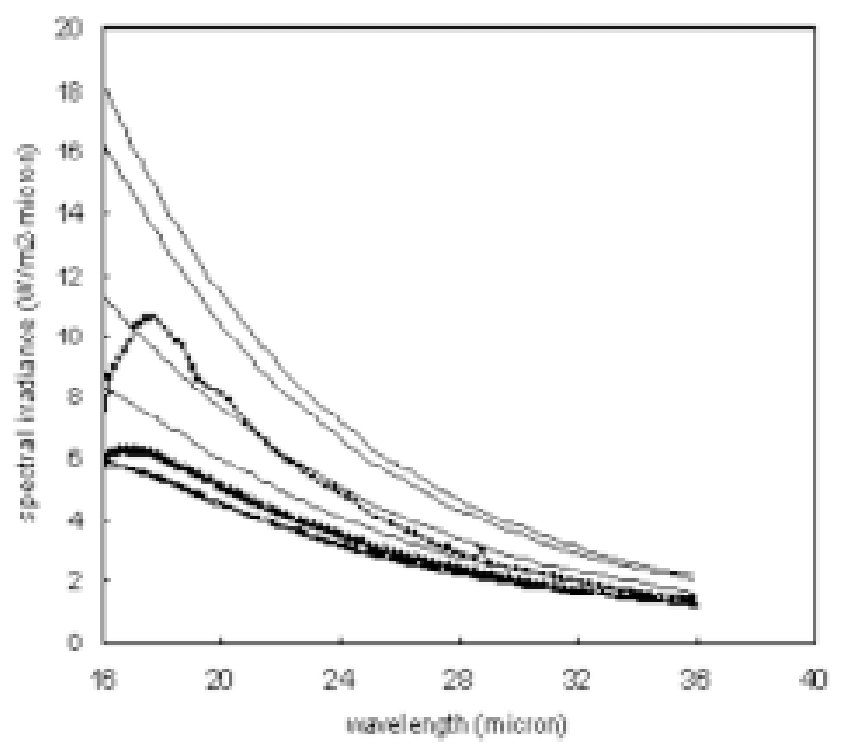

Figure 4 - Spectral outgoing irradiances as in Figure 3 , for the $\lambda>15 \mu \mathrm{m}$ interval. Figura 4 - Irradiâncias espectrais emergentes como na Figura 3, para o intervalo $\lambda>15 \mu \mathrm{m}$.

for GOES channels $3,4,5$. An intermediate virtual channel for $\lambda=8.5$ $\mathrm{mm}$ is considered, for which brightness temperature is the same as for channel 4. Integral on the right side of eq. (6) corresponds to a remaining blackbody "tail" beginning at a proper wavelength $\lambda$ " $>15 \mu \mathrm{m}$ with constant temperature $T^{*}<T_{11}$ mainly associated to effects of water vapor continuum. It is seen that $T^{*}$ is close to $T_{11}=T_{12}$ for high-level cloud, since water vapor density above cloud top is considerably low.

A simple parameterization for the "blackbody tail" integral may be built as follows. Integral expression

$$
I(\lambda, T)=1-\frac{1}{B} \int_{0}^{\lambda} B_{\lambda}(\lambda, T) d \lambda
$$

(where $B=\sigma T^{4}$ and $0 \leq I \leq 1$ ) is actually a function of a single variable $x=\lambda T$. Proper tables for this function can be found in Paltridge \& Platt (1976, chapter 2), it is found that it closely fits the potential function

$$
J(\lambda T)=0.0738(\lambda T)^{-2.48}
$$

for $\lambda>15 \mu \mathrm{m}$, so that

$$
\int_{\lambda}^{\infty} B_{\lambda} d \lambda \approx A(\lambda) T^{1.52}
$$

It is interesting to note that this exponent does not exactly correspond to the Rayleigh-Jeans approximation for longwave blackbody radiation (which would provide an expression proportional to $T^{*}$ ). A higher value for $\lambda^{*}$ would be required for that.

A closer observation of Figure 4 shows that brightness temperature is not constant in this wavelength interval, and proper values of $\lambda^{*}$ and $T^{*}$ should be defined for each cloudy scene. A first order (linear) correspondence between $T^{*}$ and $T_{11}$ for the extreme cases (cloudless and high-cloud cover) shown in figures 3 and 4 provides the expression

$T^{*}=47+0.76 T_{11}$,

where $T^{*}$ for the cloudless case was chosen from observation of figure 4. On the other hand, linear regression of OLR values in eq. (6) can provide the proper value for $A\left(\lambda^{*}\right)$ as well as for coefficients $a_{\mathrm{o}^{\prime}}$ $a_{6^{\prime}} a_{8^{\prime}} a_{11}, a_{12}$.

\section{ANALYSIS AND RESULTS}

Several tests for regression were performed, considering different exponents in eq. (8). Correlation coefficients were similar in all cases, so that exponent 1.52 was maintained. As a consequence, eq. (6) becomes 
$O L R \approx a_{0}+a_{6} E_{6,6}+a_{8} E_{8,11}+$

$a_{11} E_{11,11}+a_{12} E_{1,12}++\alpha\left(b+c T_{12}\right)^{1.52}$,

$E_{m, n}=\pi B_{\lambda}\left(\lambda_{m}, T_{n}\right)$

Here, the last term on the right corresponds to the "blackbody tail" for $\lambda>15 \mu \mathrm{m}$ as described by eqs. (8) and (9).

Coefficients in eq. (10) were calculated for two days (165 and 166) by linear regression, assuming ITPP5 OLR estimates as true valves. In order to test the generality of results, these regression coefficients were used for assessing OLR for julian day 170. All TOVS pixels (a set size of 6116) were considered. Table 1 illustrates the quality of approximations when several choices of GOES variables are adopted. It is seen that the mean difference $m d$ between GOES estimate and ITPP5 values is about $+3 \mathrm{~W} \cdot \mathrm{m}^{-2}>0$ with standard deviation of about 11 W. $\mathrm{m}^{-2}$ in all cases. The squared correlation coefficient $R^{2}$ estimates the quality of regression: $87 \%$ of the variance is explained by the GOES approximation. The regression GOES | ITPP5 shows that GOES approximation overestimates OLR values for "colder" TOVS pixels (associated to developed cloud systems), so that the constant term is higher than $20 \mathrm{~W} \cdot \mathrm{m}^{-2}$ in all cases. This behavior can be attributed to the higher frequency of clear-sky TOVS pixels, forcing GOES approximation to better reproduce high-valued rather than low-valued OLR cases.

In order to compensate the above mentioned effect, an objectively weighted approximation was tested. ITPP5 OLR values were con- sidered in steps of $1 \mathrm{~W} \cdot \mathrm{m}^{-2}$, and the corresponding mean values of GOES irradiances were adopted. Therefore, similar weights were attributed to higher as well as to lower OLR values. Table 2 presents the results. Statistically, similar values are shown for $m e$, sand $R^{2}$; however, constant term in GOES | ITPP5 regression is lower (about 18 W. $\mathrm{m}^{-2}$ or less), especially when considering all GOES variables involved. As in Table 1, it is seen that similar quality is shown by the complete approximation proposed by (10) and by a simpler approximation which considers only channel 4 information (radiance in $11 \mu \mathrm{m}$ and irradiance in the longwave tail). Figures 5 illustrate the quality of both approximations. Case (a) considers all points with the same weight, overestimation being evident for lower OLR. Bias is not seen in case (b), which allows equal weights for each $1 \mathrm{~W} \cdot \mathrm{m}^{-2}$ OLR interval. Similar behavior is observed in case (c), considering only channel 4 and longwave tail. Nevertheless, the latter case shows overestimation of about $7 \mathrm{~W} . \mathrm{m}^{-2}$ for clear-sky conditions. Coefficients for cases (b) and (c) are described in Table 3.

The extent of usefulness of estimates described by Table 3 was tested by considering their skill for a different epoch of the year. Comparison with ITPP5 estimates for julian day 239 (in August, about 3 months later) showed values $m e \approx-2, s \approx 12 \mathrm{~W} \cdot \mathrm{m}^{-2}$ and $R^{2}=0.94$. This result suggests that the coefficients in Table 3 exhibit an acceptable degree of confidence to describe OLR values along the entire year (that is, they constitute a physical synthesis of the different radiative properties of cloud systems over the region).

It could be argued that standard deviation of GOES estimates is rather high. Nevertheless, such figures describe the case of single TOVS
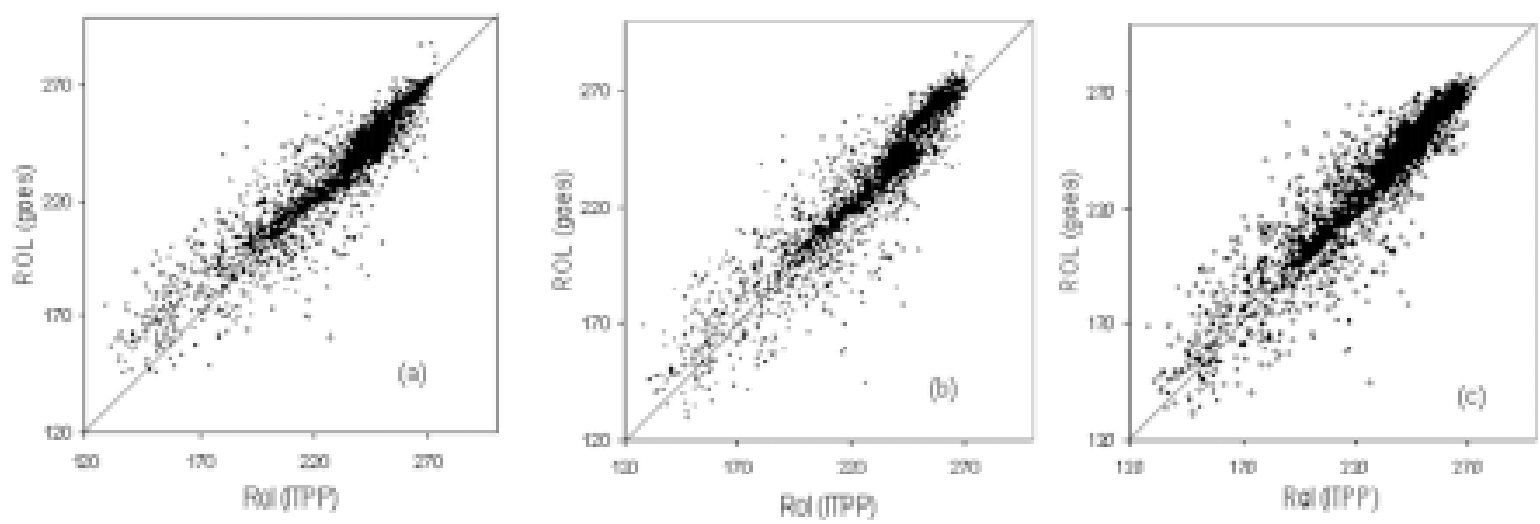

Figures 5 - GOES algorithm versus ITPP assessment: (a) using all variables, equal weight for all points; (b) grouping GOES pixels within I W. m² OLR intervals (ITPP assessment) and considering all variables; (c) using criterion (b), but considering only channe/ 4 and "longwave tail".

Figuras 5 - Algoritmo GOES versus estimativa ITPP: (a) usando todas as variáveis, com pesos iguais para todos os pontos; (b) grupando pixels GOES de acordo com intervalos de 7 W. $m^{-2}$ (ROL estimada pelo SBDART) e considerando todas as variáveis; (c) usando o critério (b), mas considerando apenas o canal 4 e a cauda de onda longa. 
targets (about $20 \mathrm{~km}$ diameter). It is worthwhile to note that usual reports of OLR values (for example those of NCEP) are provided as means in a $2.5^{\circ}$ ' $2.5^{\circ}$ grid. For analyzing this aspect, means of GOES approximation (simpler case) were estimated for TOVS pixels included in $1^{\circ} \times 1^{\circ}$ cells, julian day 239. Table 4 summarizes statistical results when considering the "all pixels" and "weighted OLR" approximations. It is seen that all cases exhibit similar quality, but the "weighted OLR" criterion shows lower bias (about $2.6 \mathrm{~W} \cdot \mathrm{m}^{-2}$ ). Standard deviation is about 7 W. $\mathrm{m}^{-2}$. Note that means over larger cells could be even lower. These results are fairly good, when comparing with the accuracy of AVHRRbased estimates in $2.5^{\circ} \times 2.5^{\circ}$ cells (GRUBER et al., 1994).

Figures 6 illustrate the results provided by the use of coefficients in Table 3. It is seen that OLR fields for ITPP and simpler GOES assessment show similar patterns. The difference between GOES and ITPP as-

Table 1 - Mean difference and standard deviation for errors of GOES model adopting several choices of GOES variables and assuming ITPP5 as true reference. Day: June 19, 2001. Variables considered: all TOVS pixels and corresponding GOES variables, for June 14 and 15, 2001.

Tabela 1 - Desvio médio e desvio padrão para erros do modelo GOES para várias escolhas de variáveis GOES, supondo estimativas ITPP5 como referência. Dia 19/ 06/2001. Variáveis consideradas: todos os píxeis TOVS e as variáveis GOES correspondentes, para 14 e 15/06/2001.

\begin{tabular}{|ccccccc|}
\hline Variables & all & $\begin{array}{c}8,11,12, \\
\text { tail }\end{array}$ & $\begin{array}{c}6,8,12, \\
\text { tail }\end{array}$ & $\begin{array}{c}6,8,11, \\
\text { tail }\end{array}$ & $\begin{array}{c}8,11, \\
\text { tail }\end{array}$ & $\begin{array}{c}11, \\
\text { tail }\end{array}$ \\
\hline Mean difference, $m$ md & 3.0 & 1.9 & 3.2 & 2.1 & 0.7 & 1.0 \\
Standard deviation, $s$ & 10.7 & 10.6 & 10.6 & 10.9 & 10.9 & 10.9 \\
$\mathrm{R}^{2}$ & 0.87 & 0.87 & 0.87 & 0.86 & 0.86 & 0.86 \\
Regression /ITPP5 & $0.84 x+39$ & $0.88 x+29$ & $0.89 x+29$ & $0.84 x+38$ & $0.89 x+25$ & $0.91 x+21$ \\
\hline
\end{tabular}

Table 2 - Mean and standard deviation for errors of GOES model adopting several choices of GOES variables and assuming ITPP5 as true reference. Day: June 19, 2001. Variables considered: 1 w.m.-2 steps for ITPP5 values, and respective means for GOES variables, for June 14 and 15, 2001.

Tabela 2 - Valor médio e desvio-padrão para os erros do modelo GOES, para várias escolhas de variáveis GOES e supondo as estimativas ITPP5 como verdadeiras. Dia 19/06/2001. Variáveis consideradas: intervalos de 1 W. $\mathrm{m}^{2}$ para valores de ITPP5 e as médias respectivas para variáveis GOES, para os dias 14 e 15/06/2001.

\begin{tabular}{|ccccccc|}
\hline Variables & all & $\begin{array}{c}8,11,12, \\
\text { tail }\end{array}$ & $\begin{array}{c}6,8,12, \\
\text { tail }\end{array}$ & $\begin{array}{c}6,8,11, \\
\text { tail }\end{array}$ & $\begin{array}{c}8,11, \\
\text { tail }\end{array}$ & $\begin{array}{c}11, \\
\text { tail }\end{array}$ \\
\hline Mean difference & 1.5 & 3.1 & 1.3 & 0.3 & 1.7 & 3.2 \\
Standard deviation & 11.0 & 10.6 & 11.6 & 11.2 & 10.9 & 11.0 \\
$\mathrm{R}^{2}$ & 0.87 & 0.87 & 0.85 & 0.86 & 0.86 & 0.86 \\
Regression /ITPP5 & $0.95 x+14$ & $0.90 x+25$ & $0.94 x+14$ & $0.94 x+14$ & $0.90 x+24$ & $0.90 x+18$ \\
\hline
\end{tabular}

Table 3 - Regression coefficients for approximations described in Table 2.

Tabela 3 - Coeficientes de regressão para as aproximações descritas na Tabela 2.

\begin{tabular}{|lcccccc|}
\hline Coefficients & $a_{\mathrm{o}}$ & $a_{6}$ & $a_{8}$ & $a_{11}$ & $a_{12}$ & $\alpha$ \\
\hline All variables & -1166.6 & -8.59 & -241.6 & 25.3 & 141.8 & 0.441 \\
Simpler approximation & -493.7 & & & -16.96 & & 0.187 \\
\hline
\end{tabular}

Table 4 - Comparison between GOES approximation and ITPP5 estimates for means over $1^{\circ} \times 1^{\circ}$ cells, julian day 239.

Regression cases described in Tables 1 and 2 are included.

Tabela 4 - Comparação entre aproximação GOES e estimativas ITPP5 para médias sobre células de 1× $1^{\circ}$, dia juliano 239.

São incluídos os casos descritos nas Tabelas l e 2 .

\begin{tabular}{|l|cc|cc|}
\hline Approximations & \multicolumn{2}{c|}{ All pixels (Table 1) } & \multicolumn{2}{c|}{ Weighted (Table 2) } \\
\hline Variables & All & 11, tail & All & 11, tail \\
Mean difference & 3.8 & 2.0 & 2.6 & 4.2 \\
Standard deviation & 6.9 & 6.9 & 6.8 & 6.6 \\
\hline
\end{tabular}


sessment is also shown. It is seen that residuals lie within $\pm 7 \mathrm{~W} \cdot \mathrm{m}^{-2}$ over most part of the region. GOES approximation deviates mainly 7-14 W. $\mathrm{m}^{-2}$ over cloudy and clear-sky areas. Higher deviations are present in restricted areas; except on the left side of the figure; on one hand, image boundary may induce lower-quality interpolation of radiation field; on the other hand, times for NOAA-14 overpass and GOES image are not exactly the same, and OLR values may have changed for some cloud systems.
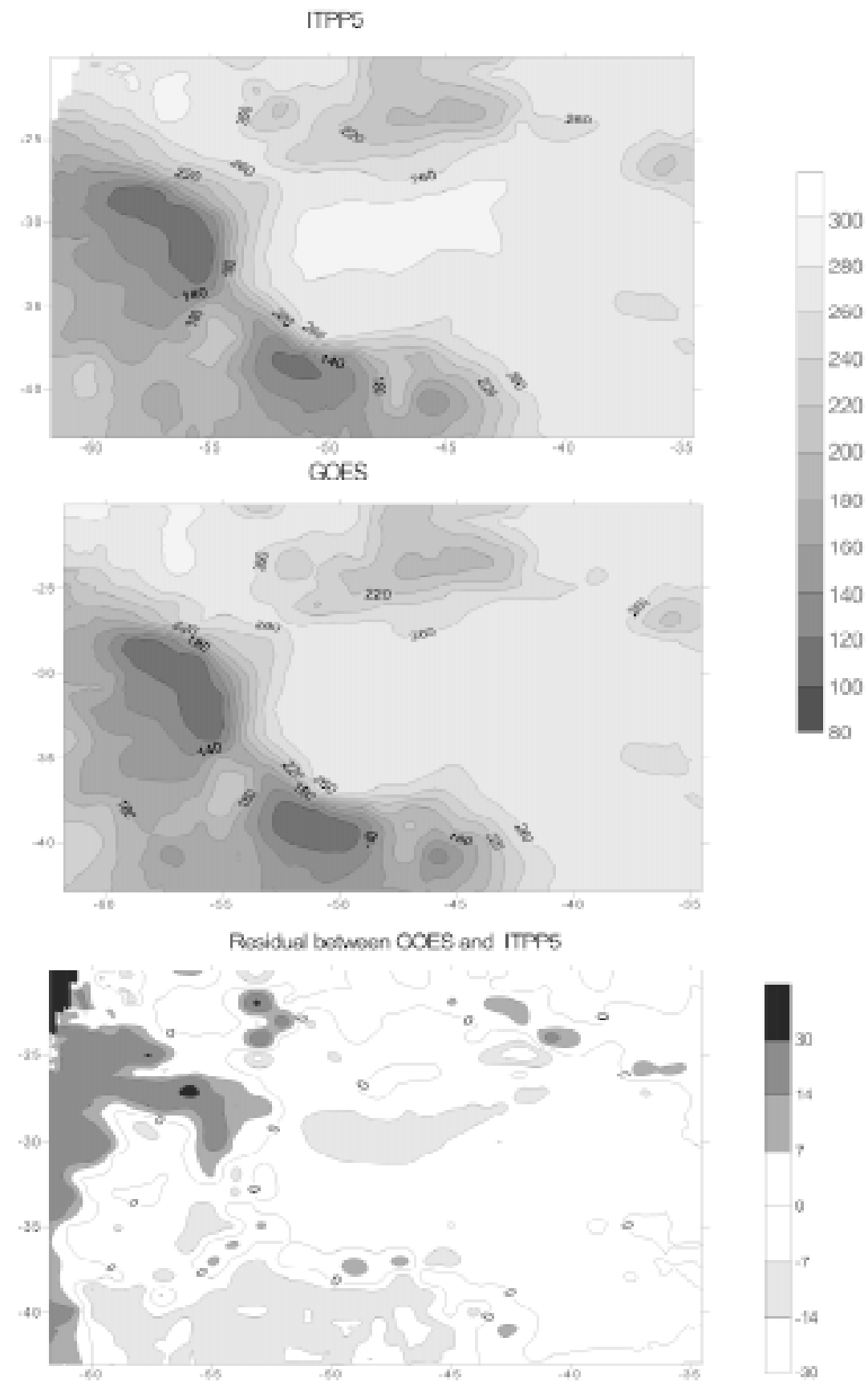

Figure 6 - Comparison of GOES approximation with ITPP5 estimates for $1 \times 1$ degree cells. Figura 6 - Comparação entre a aproximação GOES e a estimativa ITPP5 para células de $1^{\circ} \times 7^{\circ}$. 


\section{CONCLUSIONS}

In spite of the simplifying assumptions for estimates of TOA outgoing irradiance, GOES Imager provides approximations to OLR over the Brazilian region which are compatible with other estimates based on AVHRR/NOAA information (GRUBER et al., 1994). A simple algorithm shows errors with mean deviation of about 3 W. $\mathrm{m}^{-2}$ and standard deviation of $11 \mathrm{~W} . \mathrm{m}^{-2}$. This paper assumes ITPP5 estimate based on HIRS/ NOAA 14 as a reference "true value" for OLR.

The algorithm (a multivariate regression of GOES irradiances on OLR reference value) considers GOES channels $3(6.4 \mu \mathrm{m}), 4(11 \mu \mathrm{m})$ and $5(12 \mu \mathrm{m})$, adding a virtual channel in $8 \mathrm{~mm}$ and a longwave tail $(\lambda>15 \mu \mathrm{m})$. Nevertheless, similar statistical errors are obtained by a linear combination of channel 4 irradiance and the longwave tail only.

A better regression is obtained by assigning equal weights to OLR values rather than to single pixels. Sets of GOES pixels (and their mean radiances) were considered, classified according to steps of 1 W.m2 in OLR. This criterion corrects overestimation of OLR for cloudy conditions (lower OLR values).

When coefficients obtained for June 2001 are used for OLR assessment in August 2001, averages over a $1^{\circ} \times 1^{\circ}$ grid show errors with standard deviation of $\pm 7 \mathrm{~W} \cdot \mathrm{m}^{-2}$. Absolute errors lower than $14 \mathrm{~W} \cdot \mathrm{m}^{-2}$ lie over the most part of NOAA overpass. This result suggests that the algorithm describes physical rather than statistical or seasonal properties of outgoing longwave flux. Given the better resolution and higher frequency of GOES imagery, a detailed monitoring of daily and seasonal cycles of OLR over South American region could be allowed. Further analysis and improvements of these aspects are recommended, especially comparisons with other OLR estimation models available for NOAA 14 and 16 and "absolute" measurements like those of CERES sensor.

\section{Acknowledgements}

This work was partially supported by CNPq/MCT research fellowship of first author and CAPES/MEC graduate studies fellowship of the others.

\section{REFERENCES}

BAKSTROM, B. R. Ceres: the start of the next generation of radiation measurements. Adv. Space Res., Elsevier, v. 24, p. 907-914, 1999. CALVET, J. C.; VISWANADHAM, Y. Amazon forest radiation budget from satellite data. American Meteor. Soc., Boston, v. 32, p. 844-847, 1993.
ELLINGSON, R. G.; FERRARO, R. R. An examination of a technique for estimating the longwave radiation budget from satellite radiance observations. American Meteor. Soc., Boston, v. 22, p. 1416-1423, 1983.

; LEE, H.-T.; YANUK, D. Validation of a technique for estimating Outgoing Longwave Radiation from HIRS radiance observations. American Meteor. Soc., Boston, v. 11, p. 357-365, 1994.

et al. A technique for estimating outgoing longwave radiation from HIRS radiance observations. American Meteor. Soc., Boston, v. 6, p. 706-711, 1989.

GRUBER, A.; KRUEGER, A. F. The status of the NOAA outgoing longwave radiation data set. American Meteor. Soc., Boston, v. 65, p. 958-982, 1984.

et al. A comparison of ERBE and AVHRR longwave flux estimates. American Meteor. Soc., Boston, v. 75, p. 2115-2130, 1994.

GUBE, M. Radiation budget parameters at the top of the Earth's atmosphere derived from Meteosat data. American Meteor. Soc., Boston, v. 21, p. 1907-1921, 1982.

KIDDER, S. Q.; VONDER HAAR, T. Satellite meteorology: an introduction. [New York]: Academic Press, 1995.

LIOU, K .N. An introduction to atmospheric radiation. New York: Academic Press, 1980.

MAMOUDOU, B. B.; ELLINGSON, R. G. A study of diurnal cycle of OLR using GOES Sounder data. In: INTERNATIONAL RADIATION SYMPOSIUM, 2000. St. Petersburg, 2000: Current Problems in Atmospheric Radiation St. Petesburg: A. Deepak Pub., 2001, p. 505-508.

MCCLATCHEY, R. A. et al. Optical properties of the atmosphere. AFCRL Environmental Research Papers, Air Force Cambridge Research Laboratory, Bedford, n. 411, 1972

PALTRIDGE, G. W.\&C.M.R. PLATT, C.M.R. Radiative processes in meteorology and climatology. Amsterdan: Elsevier, 1976.

RAMANATHAN, V. et al. Cloud radiative forcing and climate: results from the earth Radiation budget experiment. Science, [S.I.], v. 243, p. 5763, 1989

RICCHIAZZI, P. et al. SBDART: a research and teaching software tool for plane-parallel radiative transfer in the Earth's atmosphere. American Meteor. Soc., Boston, v. 79, n. 10, p. 2101-2114, 1998.

et al. SBDART: a practical tool for plane-parallel radiative transfer in the Earth's atmosphere, 2000. http:// www.crseo.ucsb.edu/esrg/pauls dir. Acesso em

SCHMETZ, J.; LIU, Q. Outgoing longwave radiation and its diurnal variation at regional scales derived from Meteosat. American Geophys. Union, Washington, DC, v. 93, n. D9, p. 11192-11204, 1988. 


\section{NOTAS SOBRE OS AUTORES}

Juan Carlos Ceballos é formado em Física (Universidad Nacional de Tucumán-UNT, Argentina, 1966), Doutor em Meteorologia (IAGUSP, 1986). Pós-doutorado no Laboratoire d'Optique Atmosphérique, Université de Lille (França). Lecionou na UNT (1966-1976) e na Universidade Federal da Paraíba (UFPB, 1976-1996); atualmente, pesquisador na Divisão de Satélites e Sistemas Ambientais (DSACPTEC-INPE, desde 1996).

Wagner Flauber de Araújo Lima é formado em Meteorologia (bacharel, UFPB, 2000; mestre, INPE, 2004). Atualmente, membro da equipe técnica da Divisão de Satélites e Sistemas Ambientais (DSA-CPTEC-INPE).

Jaidete Monteiro de Souza é bacharel (UFPB, 1996) e formada em Meteorologia. Mestre (UFPBE, 1998). Doutora (INPE, 2004). Atualmente leciona na Universidade Federal de Itajubá, MG. 